UDK 616.13-004.6:616.12-008.33]-053-055-07

https://doi.org/10.26641/2307-0404.2020.3.214809

\section{J.R. Bosdriesz ${ }^{1}$, V.V.Semenov ${ }^{2}$, O.V. Kuryata ${ }^{2}$}

\title{
THE ASSOCIATION OF CORONARY ARTERY CALCIUM SCORE WITH GLOMERULAR FILTRATION RATE AND THE INFLUENCE OF SEX, AGE, BLOOD PRESSURE, AND CHOLESTEROL
}

\author{
Amsterdam UMC, University of Amsterdam ${ }^{1}$ \\ Department of Medical Informatics, Amsterdam Public Health Institute \\ Spui str., 21, Amsterdam, 1012 WX, The Netherlands \\ $S E$ «Dnipropetrovsk medical academy of Health Ministry of Ukraine» ${ }^{2}$ \\ Department of Internal Medicine 2 and Phtisiatry \\ V. Vernadsky str., 9, Dnipro, 49044, Ukraine \\ Амстердам УМЦ, Амстердамський університет ${ }^{l}$ \\ кафедра медичної інформатики, Інститут громадського здоров'я \\ Амстердам, 1012, Нідерланди \\ ДЗ “Дніпропетровська медична академія МОЗ України”, \\ кафедра внутрішньої медицини 2 і фтизіатріі \\ вул. В. Вернадського, 9, Дніпро, 49044, Україна \\ e-mail: semenovviktvikt@gmail.com
}

\author{
Цитування: Медичні перспективи. 2020. Т. 25, № 3. С. 71-76 \\ Cited: Medicni perspektivi. 2020;25(3):71-76
}

Key words: coronary artery calcium score, glomerular filtration rate, sex, age, blood pressure, cholesterol Ключові слова: індекс кальцифікачії коронарних артерій, ивидкість клубочкової фільтрачії, стать, вік, артеріальний тиск, холестерин

Ключевые слова: индекс кальциификации коронарных артерий, скорость клубочковой фильтрации, пол, возраст, артериальное давление, холестерин

\begin{abstract}
The association of coronary artery calcium score with glomerular filtration rate and the influence of sex, age, blood pressure, and cholesterol. Bosdriesz J.R., Semenov V.V., Kuryata O.V. Chronic kidney disease puts an individual at a higher risk of all-cause and cardiovascular death. Coronary artery calcium score reflects the accumulation of calcium in the walls of the coronary arteries and a higher coronary artery calcium score is associated with lower survival rates. It is unclear if control of conventional risk factors is enough to reduce cardiovascular risk in patients with chronic kidney disease. The aim of this study was to investigate if the association between estimated glomerular filtration rate and coronary artery calcium score in the Ukrainian population differs by sex, age, blood pressure, and total cholesterol. This cross-sectional study was conducted on a sample of patients who underwent measurement of coronary artery calcium score at Dnipropetrovsk Mechnikov Regional Hospital, Dnipro, Ukraine. Inclusion criteria: age $>40$ years old, available data about coronary artery calcium score and estimated glomerular filtration rate. Exclusion criteria: the presence of known cardiovascular disease, diagnosis of diabetes mellitus, estimated glomerular filtration rate $<30 \mathrm{ml} / \mathrm{min}$ and extreme coronary artery calcification (coronary artery calcium score $>1500$ Agatston units). 137 patients (54 males and 83 females), median age 59.0 [54.0;67.0] years were enrolled in the study. In the patients with lower eGFR there was non-significantly higher coronary artery calcium score ( $p=0.07)$. In males with eGFR $\geq 90 \mathrm{ml} / \mathrm{min}, 60-89 \mathrm{ml} / \mathrm{min}$, and 30-59 ml/min coronary artery calcium score didn't differ significantly, while in females a lower estimated glomerular filtration rate was associated with a higher coronary artery calcium score. A lower estimated glomerular filtration rate was significantly associated with a higher coronary artery calcium score in the patients with systolic blood pressure $\geq 140 \mathrm{mmHg}(p=0.04)$, but not in patients with diastolic blood pressure $\geq 90 \mathrm{mmHg}$. In the patients with total cholesterol $<5.0 \mathrm{mmol} / \mathrm{l}$ and $\geq 5.0 \mathrm{mmol} / \mathrm{l}$ coronary artery calcium score tended to be higher in the patients with lower estimated glomerular filtration rate. A lower estimated glomerular filtration rate in our study was associated with a higher coronary artery calcium score in females, patients aged $\geq 55$ years old and in patients with systolic blood pressure $\geq 140 \mathrm{mmHg}$.
\end{abstract}

Реферат. Асоціація індексу кальцифікації коронарних артерій зі швидкістю клубочкової фільтрації та вПлив статі, віку, артеріального тиску та холестерину. Боздрієз Й.Р., Семенов В.В., Курята О.В. При хронічній хворобі нирок спостерігається підвищений ризик загальної та сериево-судинної смерті. Індекс кальцицфікаиії коронарних артерій відображає накопичення кальиію в стінках коронарних артерій, більи 
високий індекс кальциифікації коронарних артерій асоціюється з нижчими показниками виживаності. Питання про ефективність контролю стандартних факторів ризику для зменшення серцево-судинного ризику в пацієнтів із хронічною хворобою нирок залишається відкритим. Метою иьього дослідження було визначити, чи відрізняється асоціація між розрахованою швидкістю клубочкової фільтрації та індексом кальцифікації коронарних артерій в Украӥнській популяиії залежно від статі, віку, артеріального тиску та загального холестерину. Це одномоментне дослідження було проведено на вибіриі пацієнтів, шчо пройшли дослідження індексу кальцифікаџії коронарних артерій у Дніпропетровській обласній клінічній лікарні ім. I.I. Мечникова, м. Дніпро, Україна. Критерії включення: вік >40 років, наявні дані про індекс кальцифікації коронарних артерій та розраховану швидкість клубочкової фільтрачії. Критерії виключення: наявність відомої сериево-судинної патологіі, діагноз иукрового діабету, розрахована швидкість клубочкової фільтрачї <30 мл/хв. та надмірно високий індекс кальцифікації коронарних артерій (>1500 балів за шкалою Агатстона). У дослідження було включено 137 пацієнтів (54 чоловіків та 83 жінки), медіана віку 59,0 [54,0; 67,0] років. У пацієнтів із нижчою розрахованою швидкістю клубочкової фільтрації спостерігався статистично незначуще вищий індекс кальцифікації коронарних артерій $(p=0,07)$. У чоловіків із розрахованою чвидкістю клубочкової фільтрації $\geq 90$ мл/хв., 60-89 мл/хв. і 30-59 мл/хв. індекс кальц̧ифікації коронарних артерій не суттєво відрізнявся, тоді як у жінок нижча розрахована швидкість клубочкової фільтрації асоиіювалася з вищим індексом кальцифікації коронарних артерій. Нижча розрахована ивидкість клубочкової фільтрації достовірно асоціювалася з вищим індексом кальц̧ифікації коронарних артерій у пацієнтів з систолічним артеріальним тиском $\geq 140$ мм рт. ст. (p=0,04), але не в пацієнтів з діастолічним артеріальним тиском $\geq 90$ мм рт. ст. $У$ пацієнтів із загальним холестерином <5,0 ммоль/л та $\geq 5,0$ ммоль/л спостерігалася тенденція до вищого індексу кальцифікації коронарних артерій, чим у пацієнтів із нижчою розрахованою швидкістю клубочкової фільтрації. Нижча розрахована швидкість клубочкової фільтрації в намому дослідженні асоціювалася 3 вищим індексом кальцифікації коронарних артерій у жінок, пацієнтів віком понад 55 років та в пацієнтів із систолічним артеріальним тиском $\geq 140$ мм рт. $\mathrm{cm}$.

Chronic kidney disease (CKD) puts an individual at a higher risk of all-cause and cardiovascular death, starting from the decline of the glomerular filtration rate (GFR) below $90 \mathrm{ml} / \mathrm{min}$ [4]. Coronary artery calcium score (CACS) reflects the accumulation of calcium in the walls of the coronary arteries and a higher CACS is associated with lower survival rates [11]. The progression of atherosclerosis and the accumulation of coronary calcium in CKD is more rapid, than in the general population, due to the presence of additional CKD-related risk factors [1].

An increased risk of death may be a reason to attempt to prevent further decline of renal function and to achieve stricter target values for blood pressure and blood lipids $[10,18]$. However, there is some discussion about the target blood pressure values $[17,18]$ and the rationale of treatment with statins for patients with CKD [10]. It is unclear if control of conventional risk factors is enough to reduce cardiovascular risk in patients with CKD.

Both reduction of renal function and changes in presentation of conventional cardiovascular risk factors (i.e. age, blood pressure and total cholesterol (TC)) may influence the accumulation of coronary artery calcium [7, 14]. However, in the Ukrainian population, cardiovascular disease and CKD develop earlier than in other European regions $[12,16]$. This, in turn, may influence the association between GFR and CACS with conventional cardiovascular risk factors. The aim of this study was to investigate if the association between glomerular filtration rate and coronary artery calcium score in the Ukrainian population differs by sex, age, blood pressure, and total cholesterol.

\section{MATERIALS AND METHODS OF RESEARCH}

Study population. This cross-sectional study was conducted on a sample of patients who underwent measurement of CACS at Dnipropetrovsk Mechnikov Regional Hospital, Dnipro, Ukraine. Inclusion criteria: age $>40$ years old, available data about CACS and eGFR. Exclusion criteria: presence of known cardiovascular disease, diagnosis of diabetes mellitus, eGFR $<30 \mathrm{ml} / \mathrm{min}$ and extreme coronary artery calcification (CACS $<1500$ Agatston units (AU)).

CACS was estimated after cardiac computed tomography using Optima CT660, GE Healthcare, Wisconsin, USA (2017), and reported in AU. CACS was classified into three groups according to ESC/EAS 2019 guidelines: $0 \mathrm{AU}, 1-100 \mathrm{AU}$ and $>100$ AU [19]. eGFR was calculated using the CKDEPI equation, which requires data about patient's sex, age and serum creatinine [9]. Patients were classified into groups by eGFR according to KDIGO stages of chronic kidney disease [9]. Blood pressure was measured using automated methods. Stratification of patients by the level of systolic blood pressure (SBP) $\geq 140 \mathrm{mmHg}$ and diastolic blood pressure (DBP) $\geq 90 \mathrm{mmHg}$ was performed according to recommended blood pressure targets in treatment of arterial hypertension [18]. Measurements of total cholesterol (TC) and serum creatinine were performed using standard procedures. Stratification of patients by the level of 
$\mathrm{TC} \geq 5.0 \mathrm{mmol} / 1$ was performed according to European Guidelines on cardiovascular disease prevention in clinical practice [5].

Data were analyzed using LibreOffice and $\mathrm{R}$ (version 3.6.3) [6, 15]. The type of data distribution was assessed using Shapiro-Wilk tests. As all the variables in the study had a non-normal distribution, non-parametric statistical methods were applied. Continuous data were reported as median with the first and the third quartiles (Me [Q1;Q3]). Assessment of the difference of medians of continuous variables between two groups was performed using a Mann-Whitney test. Assessment of difference of medians of continuous variables between three groups was performed using a Kruskal-Wallis test. The significance of the trend in medians was assessed with a Jonckheere-Terpstra test. Categorical data were reported as $\mathrm{n}(\%)$, and were compared using a Chi-square test. The critical value of $p$ values in testing statistical hypotheses was defined as $\mathrm{p}<0.05$ [13].

\section{RESULTS AND DISCUSSION}

Percentage of females in the study was slightly higher than men, but the sex difference of patients with eGFR $\geq 90 \mathrm{ml} / \mathrm{min}$, eGFR $60-89 \mathrm{ml} / \mathrm{min}$, and eGFR $30-59 \mathrm{ml} / \mathrm{min}$ was the same (Table). In the patients with lower eGFR there was a significantly higher age $(p=0.01)$ and non-significantly higher CACS $(p=0.07)$. All the patients in the study had a $\mathrm{BP}$ close to the upper recommended target value of $140 / 90$ or exceeded it. TC values of all patients were close to or higher than the upper normal limit of $5.0 \mathrm{mmol} / \mathrm{l}$ regardless of eGFR category. Among the patients with lower eGFR there was a lower proportion of patients with $\mathrm{CACS}=0 \mathrm{AU}$ and a higher proportion of patients with CACS $>100 \mathrm{AU}$. However, this difference was not statistically significant. The proportion of patients with CACS 1$100 \mathrm{AU}$ was equal regardless of eGFR. The proportion of patients with CACS $>100 \mathrm{AU}$ and median CACS increased abruptly in the patients with eGFR $30-59 \mathrm{ml} / \mathrm{min}$, when compared to the patients with eGFR $60-89$ and $\geq 90 \mathrm{ml} / \mathrm{min}$.

In males with eGFR $\geq 90 \mathrm{ml} / \mathrm{min}$, eGFR 60$89 \mathrm{ml} / \mathrm{min}$, and eGFR 30-59 $\mathrm{ml} / \mathrm{min}$ CACS didn't differ significantly, while in females lower eGFR was associated with higher CACS (Fig.). Moreover, the median CACS in males $(50[5 ; 200]$ AU) was higher than in females $(10[0 ; 103] \mathrm{AU}, \mathrm{p}=0.02)$. A higher CACS was associated with a lower eGFR in patients aged above 55 years old $(\mathrm{p}=0.01)$, but not in patients younger than 55 years old. In older patients, the median CACS was higher $(52[4 ; 156]$ AU), than in younger patients $(0[0 ; 29] \mathrm{AU}, \mathrm{p}<0.01)$. A lower eGFR was significantly associated with a higher CACS in the patients with $\mathrm{SBP} \geq 140 \mathrm{mmHg}$ ( $p=0.04$ ), but not in patients with $\mathrm{DBP} \geq 90 \mathrm{mmHg}$. In the patients with $\mathrm{SBP}<140 \mathrm{mmHg}$ and DBP $<90 \mathrm{mmHg}$, CACS was roughly the same regardless of eGFR. In the patients with $\mathrm{TC}<5.0 \mathrm{mmol} / 1$ and $\geq 5.0 \mathrm{mmol} / 1 \mathrm{CACS}$ tended to be higher in the patients with lower eGFR.

\section{Presentation of conventional cardiovascular risk factors in patients with normal, mildly reduced and moderately reduced eGFR}

\begin{tabular}{|c|c|c|c|c|c|c|}
\hline Variable & Total $(n=137)$ & $\begin{array}{c}\text { eGFR } \geq 90 \\
\mathrm{ml} / \mathrm{min}\end{array}$ & $\begin{array}{c}\text { eGFR 60-89 } \\
\mathrm{ml} / \mathrm{min}\end{array}$ & $\begin{array}{c}\text { eGFR 30-59 } \\
\mathrm{ml} / \mathrm{min}\end{array}$ & $\begin{array}{c}P \text { for } \\
\text { difference }\end{array}$ & $P$ for trend \\
\hline Females, n (\%) & $83(60.5)$ & $23(62.1)$ & $47(60.2)$ & $13(59.0)$ & 0.96 & - \\
\hline Age, years & $59.0[54.0 ; 67.0]$ & $56.0[54.0 ; 63.0]$ & $58.5[54.0 ; 66.8]$ & $66.0[57.5 ; 76.0]$ & 0.02 & 0.01 \\
\hline SBP, mmHg & $140.0[125.0 ; 150.0]$ & $\begin{array}{c}140.0 \\
{[130.0 ; 150.0]}\end{array}$ & $\begin{array}{c}135.0 \\
{[120.0 ; 143.8]}\end{array}$ & $\begin{array}{c}140.0 \\
{[122.5 ; 150.0]}\end{array}$ & 0.13 & 0.23 \\
\hline DBP, mmHg & $80.0[80.0 ; 90.0]$ & $90.0[80.0 ; 93.0]$ & $80.0[80.0 ; 90.0]$ & $80.0[80.0 ; 90.0]$ & 0.24 & 0.11 \\
\hline Total cholesterol, $\mathrm{mmol} / \mathrm{l}$ & $5.3[4.5 ; 6.0]$ & $5.2[4.4 ; 6.0]$ & $5.5[4.8 ; 6.1]$ & $5.1[4.5 ; 5.5]$ & 0.65 & 0.86 \\
\hline Total CACS, AU & $23.0[0.0 ; 116.0]$ & $14.0[0.0 ; 60.0]$ & $12.0[0.0 ; 113.5]$ & $87.0[15.0 ; 204.0]$ & 0.04 & 0.07 \\
\hline CACS $=0$ AU, n (\%) & $42(30.7)$ & $11(29.7)$ & $28(35.9)$ & 3 (13.6) & & \\
\hline CACS 1-100 AU, n (\%) & $55(40.1)$ & $18(48.6)$ & $29(37.2)$ & $8(36.4)$ & 0.10 & - \\
\hline CACS $>100$ AU, n (\%) & $40(29.2)$ & 8 (21.6) & $21(26.9)$ & $11(50.0)$ & & \\
\hline
\end{tabular}



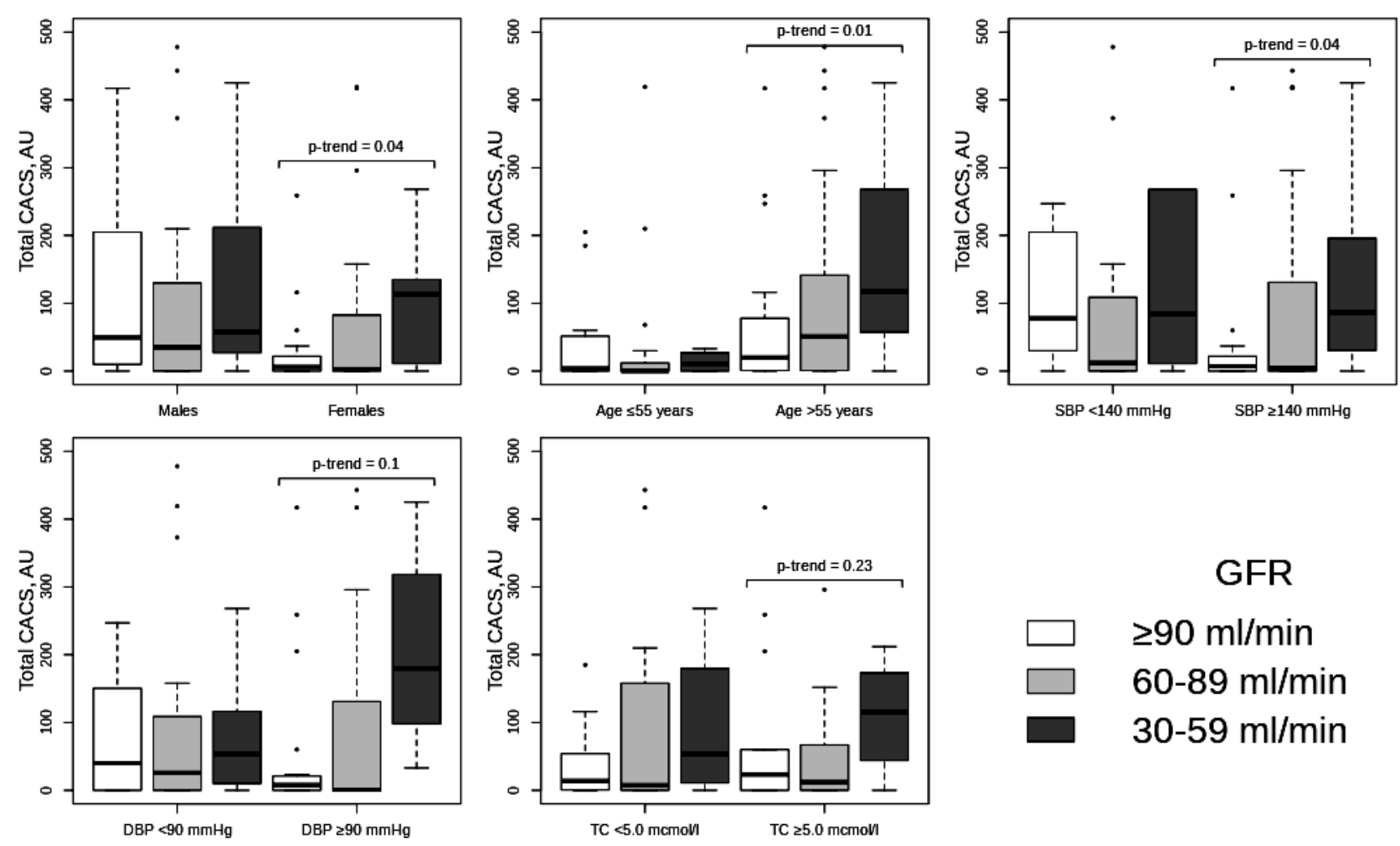

The association of eGFR category with total CACS stratified by conventional cardiovascular risk factors

Among the variables in the study only age and coronary artery calcium score were higher in the patients with lower estimated glomerular filtration rate. CACS was significantly higher in the patients with lower eGFR who were either female, older than 55 years or had a SBP $>140 \mathrm{mmHg}$, but remained roughly the same in other subgroups of patients.

The increase of CACS with the decrease of eGFR category $(\geq 90 \mathrm{ml} / \mathrm{min}, \quad 60-89 \mathrm{ml} / \mathrm{min}$, and 30 $59 \mathrm{ml} / \mathrm{min}$ ) in our study is not surprising and was well studied in the previous works [7]. A decline of renal function leads to the development of conditions specific to CKD, such as volume overload, mineral-bone disorder, inflammation etc., which in turn may cause damage to the cardiovascular system [1]. Progression of atherosclerosis with calcification of the atherosclerotic plaques happens faster in $\mathrm{CKD}$, than in the general population [1], which may be due to the development of mediosclerosis [3]. As aging is usually accompanied by physiological loss of the renal function, the association of age with decline of eGFR in our study was expected [2].

However, similar SBP, DBP and TC in patients with different eGFR ( $\geq 90 \mathrm{ml} / \mathrm{min}, 60-89 \mathrm{ml} / \mathrm{min}$, and $30-59 \mathrm{ml} / \mathrm{min}$ ) was surprising. A decline of renal function is often accompanied by an elevation of the blood pressure and an increase of the prevalence of arterial hypertension (HTN) [8]. In the more ad- vanced stages of CKD, HTN is more difficult to control, and proportion of the patients with resistant HTN is higher [8]. This finding may be explained by the treatment of the patients in the study according to the severity of arterial hypertension. The progression of CKD is often followed by the elevation of TC levels [10]. But in some cases of dyslipidemia in CKD there may be normal TC with elevated triglycerides and low-density lipoproteins and decreased high-density lipoproteins [10]. Thus, even a normal TC in the CKD lipid profile may be highly atherogenic [10], and the investigation of cholesterol fractions in patients with CKD is essential. Normally sex is regarded as an important risk factor of CKD progression [18, 19], but in our study there was no association between eGFR category and sex distribution. A slightly higher percentage of females in our study could be explained by later onset of cardiovascular disease in females than in males [12]. More females were enrolled in the study, due to the higher chance of being asymptomatic in the middle age.

The poor association of CACS with eGFR category together with the higher median CACS in males in our study may indicate a more severe course of atherosclerosis and worse cardiovascular prognosis. Lower median CACS in females with eGFR $\geq 90 \mathrm{ml} / \mathrm{min}$ and $60-89 \mathrm{ml} / \mathrm{min}$ may reflect the 
possibility of prevention of atherosclerosis progression for females in early CKD. The presence of the association of CACS with eGFR category in young patients ( $\leq 55$ years old) could be expected, as the association of the decline of eGFR with poor cardiovascular prognosis is believed to be stronger in younger individuals [2]. The paradoxical association of CACS with eGFR category after stratification by SBP and DBP, where individuals with higher blood pressure tended to have lower CACS, will require further investigation. In our study a higher TC did not result in a higher CACS. It may be implied that the patients with elevated blood pressure or TC were prescribed antihypertensive treatment, which could slow down the evolution of atherosclerosis and the accumulation of coronary calcium. Control of blood pressure and TC in our study was not strictly related to lower CACS, therefore it may be assumed that a decline of eGFR was the main factor driving the increase of CACS.
Closer attention to the early diagnosis of CKD and wider implementation of preventive measures for the reduction of eGFR may be beneficial for improving patients' outcomes.

\section{CONCLUSIONS}

A lower estimated glomerular filtration rate in our study was associated with a higher coronary artery calcium score in females, patients aged $\geq 55$ years old and in patients with systolic blood pressure $\geq 140 \mathrm{mmHg}$.

Conflict of interests. The authors declare no conflict of interest.

Acknowledgements

The authors are grateful to European Renal Association for supporting the ERA-EDTA Registry Fellowship at the Department of Medical Informatics, University of Amsterdam, during which a part of this work was performed.

\section{REFERENCES}

1. Valdivielso JM, Rodríguez-Puyol D, Pascual J, Barrios C, Bermúdez-López M, Sánchez-Niño MD, et al. Atherosclerosis in Chronic Kidney Disease: More, Less, or Just Different? Arterioscler Thromb Vasc Biol. 2019;39:1938-66.

doi: https://doi.org/10.1161/ATVBAHA.119.312705

2. Delanaye P, Jager KJ, Bökenkamp A, Christensson A, Dubourg L, Eriksen BO, et al. CKD: A Call for an AgeAdapted Definition. J Am Soc Nephrol 2019;30:1785-805. doi: https://doi.org/10.1681/ASN.2019030238

3. Chen J, Budoff MJ, Reilly MP, Yang W, Rosas SE, Rahman M, et al. Coronary Artery Calcification and Risk of Cardiovascular Disease and Death Among Patients With Chronic Kidney Disease. JAMA Cardiol 2017;2:635. doi: https://doi.org/10.1001/jamacardio.2017.0363

4. Wouters OJ, O'Donoghue DJ, Ritchie J, Kanavos PG, Narva AS. Early chronic kidney disease: diagnosis, management and models of care. Nat Rev Nephrol 2015;11:491-502.

doi: https://doi.org/10.1038/nrneph.2015.85

5. Perk J, De Backer G, Gohlke H, Graham I, Reiner Z, et al. European Guidelines on cardiovascular disease prevention in clinical practice (version 2012): The Fifth Joint Task Force of the European Society of Cardiology and Other Societies on Cardiovascular Disease Prevention in Clinical Practice (constituted by representatives of nine societies and by invited experts) * Developed with the special contribution of the European Association for Cardiovascular Prevention \& Rehabilitation (EACPR). Eur Heart J. 2012;33:1635-701. doi: https://doi.org/10.1093/eurheartj/ehs092

6. Firke S. janitor: Simple Tools for Examining and Cleaning Dirty Data. $\mathrm{R}$ package version 1.2.1. doi: https://CRAN.R-project.org/package=janitor
7. Hyun YY, Kim H, Oh K, Ahn C, Park SK, Chae DW, et al. eGFR and coronary artery calcification in chronic kidney disease. Eur J Clin Invest 2019;49:e13101. doi: https://doi.org/10.1111/eci.13101

8. Judd E, Calhoun DA. Management of Hypertension in CKD: Beyond the Guidelines. Adv Chronic Kidney Dis. 2015;22:116-22.

doi: https://doi.org/10.1053/j.ackd.2014.12.001

9. Ecnoyan G, Lameire N, Echardt K, Kasiske B, Wheeler D, Abboud O. KDIGO 2012 Clinical Practice Guideline for the Evaluation and Management of Chronic Kidney Disease. Kidney Int Suppl. 2013;3:1-150.

10. Mikolasevic I, Žutelija M, Mavrinac V, Orlic L. Dyslipidemia in patients with chronic kidney disease: etiology and management. Int $\mathbf{J}$ Nephrol Renov Dis 2017;10:35-45.

doi: https://doi.org/10.2147/IJNRD.S101808

11. de Lemos JA, Ayers CR, Levine BD, de Filipp CR, Wang TJ, Hundley WG, et al. Multimodality Strategy for Cardiovascular Risk Assessment: Performance in 2 Population-Based Cohorts. Circulation. 2017; 135:2119-32.

doi: http://doi.org/10.1161/CIRCULATIONAHA.117.027272

12. Nichols M, Townsend N, Scarborough $P$, Rayner M. Cardiovascular disease in Europe: epidemiological update. Eur Heart J 2013;34:3028-34. doi: https://doi.org/10.1093/eurheartj/eht356

13. Petrie A, Sabin C. Medical Statistics at a Glance. 4th edition. Wiley-Blackwell; 2019. p. 208.

14. Okwuosa TM, Greenland P, Burke GL, Eng J, Cushman M, et al. Prediction of Coronary Artery Calcium Progression in Individuals With Low Framingham Risk Score. JACC Cardiovasc Imaging. 2012;5:144-53. doi: https://doi.org/10.1016/j.jcmg.2011.11.008 
15. R Core Team. R: A language and environment for statistical computing. R Foundation for Statistical Computing. Austria. Available from: https://www.R-project.org/

16. Kramer A, Pippias M, Noordzij M, Stel VS, Andrusev AM, Aparicio-Madre MI, et al. The European Renal Association - European Dialysis and Transplant Association (ERA-EDTA) Registry Annual Report 2016: a summary. Clin Kidney J 2019;12:702-20. doi: https://doi.org/10.1093/ckj/sfz011

17. Whelton PK, Carey RM, Aronow WS, Casey DE, Collins KJ, Dennison Himmelfarb C, et al. 2017 ACC/AHA/AAPA/ABC/ACPM/AGS/APhA/ASH/ASPC/ NMA/PCNA Guideline for the Prevention, Detection,
Evaluation, and Management of High Blood Pressure in Adults. J Am Coll Cardiol. 2018;71:e127-248. doi: https://doi.org/10.1016/j.jacc.2017.11.006

18. Mancia G, Rosei EA, Azizi M, Burnier M, Clement DL, Coca A, et al. 2018 ESC/ESH Guidelines for the management of arterial hypertension. J Hypertens. 2018;36:1953-2041.

doi: https://doi.org/10.1097/HJH.0000000000001940

19. Mach F, Baigent C, Catapano AL, Koskinas KC, Casula M, Badimon L, et al. 2019 ESC/EAS Guidelines for the management of dyslipidaemias: lipid modification to reduce cardiovascular risk. Eur Heart J. 2020;41:11188. doi: https://doi.org/10.1093/eurheartj/ehz455

\section{СПИСОК ЛІТЕРАТУРИ}

1. Atherosclerosis in Chronic Kidney Disease: More, Less, or Just Different? / J. M. Valdivielso et al. Arterioscler Thromb Vasc Biol. 2019. Vol.39. P. 1938-1966. DOI: https://doi.org/10.1161/ATVBAHA.119.312705

2. CKD: A Call for an Age-Adapted Definition / P. Delanaye et al. J Am Soc Nephrol. 2019. Vol. 30. P. 17851805. DOI: https://doi.org/10.1681/ASN.2019030238

3. Coronary Artery Calcification and Risk of Cardiovascular Disease and Death Among Patients With Chronic Kidney Disease / J. Chen et al. JAMA Cardiol. 2017. Vol. 2. P. 635-643.

DOI: https://doi.org/10.1001/jamacardio.2017.0363

4. Early chronic kidney disease: diagnosis, management and models of care / O. J. Wouters et al. Nat Rev Nephrol. 2015. Vol. 11. P. 491-502.

DOI: https://doi.org/10.1038/nrneph.2015.85

5. European Guidelines on cardiovascular disease prevention in clinical practice (version 2012): The Fifth Joint Task Force of the European Society of Cardiology and Other Societies on Cardiovascular Disease Prevention in Clinical Practice (constituted by representatives of nine societies and by invited experts). Developed with the special contribution of the European Association for Cardiovascular Prevention \& Rehabilitation (EACPR) / J. Perk et al. Eur Heart J. 2012. Vol. 33. P. 1635-1701. DOI: https://doi.org/10.1093/eurheartj/ehs092

6. Firke S. Simple Tools for Examining and Cleaning Dirty Data: janitor. $\mathrm{R}$ package version 1.2.1. URL: https://CRAN.R-project.org/package=janitor

7. eGFR and coronary artery calcification in chronic kidney disease / Y. Y. Hyun et al. Eur J Clin Invest. 2019. Vol. 49 P. e13101. DOI: https://doi.org/10.1111/eci.13101

8. Judd E., Calhoun D. A. Management of Hypertension in CKD: Beyond the Guidelines. Adv Chronic Kidney Dis. 2015. Vol. 22. P. 116-122. DOI: https://doi.org/10.1053/j.ackd.2014.12.001

9. KDIGO 2012 Clinical Practice Guideline for the Evaluation and Management of Chronic Kidney Disease / G. Ecnoyan et al. Kidney Int Suppl. 2013. Vol. 3. P. 1-150.

10. Mikolasevic I., Žutelija M., et al. Dyslipidemia in patients with chronic kidney disease: etiology and mana- gement. Int J Nephrol Renov Dis. 2017. Vol. 10. P. 35-45. DOI: https://doi.org/10.2147/IJNRD.S101808

11. Multimodality Strategy for Cardiovascular Risk Assessment: Performance in 2 Population-Based Cohorts / J. A. de Lemos et al. Circulation. 2017. Vol. 135. P. 2119-2132.

DOI: https://doi.org/10.1161/CIRCULATIONAHA.117.0 27272

12. Nichols M., Townsend N., Scarborough P., Rayner M. Cardiovascular disease in Europe: epidemiological update. Eur Heart J. 2013. Vol.34. P. 3028-3034. DOI: https://doi.org/10.1093/eurheartj/eht356

13. Petrie A., Sabin C. Medical Statistics at a Glance. 4th edition. Wiley-Blackwell. 2019. 208 p.

14. Prediction of Coronary Artery Calcium Progression in Individuals With Low Framingham Risk Score / T. M. Okwuosa et al. JACC Cardiovasc Imaging. 2012. Vol. 5. P. 144-153.

DOI: https://doi.org/10.1016/j.jcmg.2011.11.008

15. R Core Team. R: A language and environment for statistical computing. $R$ Foundation for Statistical Computing. Vienna, Austria. https://www.R-project.org/

16. The European Renal Association - European Dialysis and Transplant Association (ERA-EDTA) Registry Annual Report 2016: a summary / A. Kramer et al. Clin Kidney J. 2019. Vol. 12. P. 702-720. DOI: https://doi.org/10.1093/ckj/sfz011

17. 2017 ACC/AHA/AAPA/ABC/ACPM/AGS/APhA/ASH/ASPC/NMA/PCNA Guideline for the Prevention, Detection, Evaluation, and Management of High Blood Pressure in Adults / P. K. Whelton et al. J Am Coll Cardiol. 2018. Vol.71. P. e127-248. DOI: https://doi.org/10.1016/j.jacc.2017.11.006

18. $2018 \mathrm{ESC} / \mathrm{ESH}$ Guidelines for the management of arterial hypertension / G. Mancia et al. J Hypertens. 2018. Vol. 36. P. 1953-2041.

DOI: https://doi.org/10.1097/HJH.0000000000001940

19. $2019 \mathrm{ESC} / \mathrm{EAS}$ Guidelines for the management of dyslipidaemias: lipid modification to reduce cardiovascular risk / F. Mach et al. Eur Heart J. 2020. Vol. 41. P. 111-188. DOI: https://doi.org/10.1093/eurheartj/ehz455 Стаття надійшла до редакції 24.03.2020 